\title{
PERAN LEMBAGA KEUANGAN SYARIAH DALAM PENGENTASAN KEMISKINAN DI PROVINSI NUSA TENGGARA BARAT
}

\author{
Nur Awwalunnisa \\ Universitas Islam Negeri Mataram \\ awwalunnisa@,uinmataram.ac.id
}

\begin{abstract}
ABSTRAK
Kemiskinan merupakan masalah yang akan selalu dihadapi oleh berbagai negara di seluruh dunia yang menyebabkan seluruh negara baik negara maju maupun negara berkembang focus membahas berbagai strategi maupun kebijakan untuk menangani masalah kemiskinan. Dalam ekonomi Islam terdapat instrument yang dapat membantu menyelesaikan masalah kemiskinan yaitu melalui penyaluran zakat dan pengembangan modal melalui Lembaga keuangan syariah baik melalui bank syariah ataupun Lembaga keuangan syariah lainnya. Provinsi Nusa Tenggara Barat sebagai salah satu provinsi di Indonesia yang penduduknya mayoritas muslim seharusnya dapat memberikan kontribusi dalam mengatasi masalah kemiskinan baik secara regional maupun nasional. Jumlah penduduk miskin di Indonesia pada tahun 2020 mengalami peningkatan jika dibandingkan dengan dua tahun sebelumnya. Salah satu alasan terjadinya peningkatan jumlah penduduk miskin ini karena terjadinya bencana global berupa Pandemic Covid-19 yang mengharuskan seluruh manusia di dunia melakukan adaptasi terhadap keadaan baru. Walaupun secara nasional jumlah penduduk miskin mengalami kenaikan, namun secara regional di Provinsi NTB menunjukkan jumlah penduduk miskin yang menurun pada tahun 2020.
\end{abstract}

Kata Kunci; Kemiskinan, Zakat, Ekonomi Islam, Lembaga Keuangan Syariah, Provinsi Nusa Tenggara Barat (NTB)

\section{PENDAHULUAN}

Kemiskinan merupakan masalah klasik yang selalu menarik untuk dibahas di seluruh dunia. Kemiskinan menggambarjan tingkat ekonomi suatu daerah ataupun negara, sehingga akan menentukan pula pertumbuhan ekonomi suatu daerah atau negara tersebut. Kemiskinan dikatakan sebagai fenomena dunia, dimana karakteristik yang dimiliki antara negara satu dengan negara lain tidaklah sama, hal ini disebabkan oleh factor geografis, kultur, system pemerintahan dan lain sebagainya. ${ }^{1}$ Kemiskinan menjadi suatu masalah yang komleks dan harus segera ditanggulang. Indonesia merupakan salah satu negara yang focus untuk mengatasi kemiskinan dengan memadukan petumbuhan dan pembangunan ekonomi. Kemiskinan di Indonesia juga

\footnotetext{
${ }^{1}$ Stamboel, Kemal A. 2012. Panggilam Keberpihakan, Srategi Mengakhiri di Indonesia. Jakarta : PT. Gramedia Pusaka Utama.
} 
masih menjadi masalah serius, meskipun secara statistic jumlah penduduk miskin di Indonesia masih sangat besar.

Data menunjukkan bahwa selama periode September 2020 persentase penduduk miskin di Indonesia sebesar 10.19\%, meningkat 0,41\% jika dibandingkan dengan data pada bulan Maret 2020. Jumlah penduduk miskin per September 2020 yaitu sebesar 27,55 juta orang dimana angka ini mengalami peingkatan sebesar 1,13 juta orang terhadap data Maret 2020. ${ }^{2}$ Peningkatan jumlah penduduk miskin di Indonesia saat ini juga dipengaruhi oleh adanya pandemic covid-19 yang mengejutkan dunia. Pandemic covid-19 ini telah mengganggu segala kegiatan manusia di segala bidang tak terkecuali dengan kegiatan ekonomi sehingga memaksa pemerintahan dalam suatu negara untuk mencari cara agar pandemic tersebut segera terastasi. Terganggunya kegiatan ekonomi ini menyebabkan banyak masyarakat yang kehilangan pekerjaan, para pelaku usaha terpaksa gulung tikar dan harus beradaptasi dengan keadaan yang baru.

Bukti adanya keseriusan negara-negara di dunia untuk mengatasi kemiskinan di negaranya yang akan berdampak pada dunia yaitu dengan disepakatinya Millennium Development Goals (MDGs) pada September 2000yang di adopsi oleh 189 negara serta ditandatangani oleh 147 kepada pemerintahan dan kepala negara pada saat Konferensi Tingkat Tinggi (KT'T) di New York. Pengimplementasian MDGs di Indenesia dan dunia mengalami keterlambatan sepuluh tahun dari pengesahannya di tahun 2000. Pemerinntah Indonesia menjelaskan bahwa keterlambatan ini disebabkan karena Indonesia masih dalam pemulihan situasi ekonomi pasca krisis 1998, sehingga pada September 2015 melalui siding umum PBB disepakati Sustainable Development Goals (SDGs) yang bertujuan untuk menjaga kesejahteraan ekonomi masyarakat secara berkesinambungan, menjaga keberlanjutan kehidupan social masyarakat, menjaga kualitas lingkungan hidup serta pembangunan yang inklusif dan terlaksananya tata kelola yang mampu menjaga peningkatan kualitas kehidupan dari satu generasi ke generasi berikutnya. ${ }^{3}$

SDGs merupakan inisiatif global yang bertujuan untuk menciptakan kehidupan manusia menjadi lebih baik dalam aspek social dan ekonomi serta dapat besinergi dengan lingkungan. Pada penyusunannya, disadari penuh bahwa inisiatif global ini tidak dapat menampikkan adanya implementasi ditingkat regional dan nasional. SDGs di tingkat regional dan nasional perlu meneguhkan Kembali semangat dan nilai SDGs yang inklusif dan partisipatif sebagaimana yang telah dibangun dalam SDGs tingkat global. Peran negara sangat kursial dalam memastikan bahwa pelaksanaan SDGs mendasarkan pada pendekatan dan strategi yang holistic antara pembangunan

\footnotetext{
${ }^{2}$ Badan Pusat Statistik. https://www.bps.go.id/pressrelease/2021/02/15/1851. Diakses pada tanggal 29 Maret 2021. Pukul 19.15 WITA.

${ }^{3}$ http://sdgs.bappenas.go.id. Diakses 29 Maret 2021. Pukul 20.04 WITA
} 
Awwalunnisa. Lembaga Keuangan Syariah dan Pengentasan Kemiskinan

ekonomi, inklusi social dan keberlanjutan lingkungan dengan tetap mengedepankan pada karakteristik dan periorotas tiap-tiap negara.

System ekonomi Islam tidak terlepas dari bank dan Lembaga keuangan. Lembaga keuangan merupakan instrument dalam menerapkan aturan dalam system ekonomi Islam dakam yang berhubungan dengan cara pengeloaan uang, dimana uang memiliki peranan penting dan Lembaga keuangan diperlukan untuk mengoperasionalkan fungsi-fungsi yang melekat pada uang. Pengembangan ekonomi dalam Islam selalu berprinsip pada konsep moral dan ketuhanan dan bersandar pada ajaran halal, baik, jujur, amanah, saling mencintai dan persaudaraan. ${ }^{4}$ Islam menjadikan zakat sebagai salah satu instrument dalam mengatasi kemiskinan, dimana zakat sendiri memiliki tujuan untuk memberikan kesejahteraan di antara kehidupan manusia. Lembaga keuangan syariah sebagai jembatan antara masyarakat yang memiliki kelebihan dana dengan masyarakat yang membutuhkan dana. Per juli 2020 nilai asset keuangan syariah di Indonesia mencapai Rp. 1.639.08 Triliun, naik sebesar 20,61\% secara year on year (yoy) dengan market share sebesar 9,68\%. ${ }^{5}$ Perkembangan BMT di Indonesia sangat baik, dimana saat ini telah berdiri sekitas 4.500 unit di seluruh Indonesia. Namun, perkembangan BMT yang cukup pesat ini tidak dimbangi dengan pendataan yang baik karena regulasi dan pengawasannya masih timpang tindih dengan regulator terkait. ${ }^{6}$

Provinsi Nusa Tenggara Barat (NTB) melalui pemerintah provinsi maupun pemerintan kabupaten/kota juga berusaha melakukan kebijakan untuk mengurangi angka kemiskinan khususnya yang ada di provinsi NTB. Secara statistic jumlah penduduk miskin di Provinsi NTB mengalami penurunan yaitu sebesar 713.887 (13,97\%) jiwa pada tahun 2020 jika dibandingkan dengan dua tahun terakhir yaitu 735.960 (14,75\%) jiwa pada tahun 2019 dan 737.460 (16.07\%) jiwa pada tahun 2018. ${ }^{7}$ Penurunan jumlah penduudk miskin ini merupakan hasil dari usaha pemerintah baik melalui Gubernur ataupun Bupati/Walikota dengan strategi-strategi atau kebijakan yang mendorong penurunan jumlah penduduk miskin. Kebijakan penanganan kemiskinan di Provinsi NTB telah dilaksanakan secara konsisten terlebih pada tahun 2014 Provinsi NTB dinobatkan sebagai suatu daerah wisata halal internasional dimana hal ini juga meningkatkan perekonomian daerah. Penghargaan sebagai wiasta halal ini juga menekan pemerintah Provinsi NTB untuk meningkatkan kualitas sumber daya manusianya terutama

\footnotetext{
${ }^{4}$ Muhammad. 2009. Lembaga Keuangan Mikro Syariah : Pergukatan Melawan Kemiskinan \& Penetrasi Ekonomi Global. Yogyakarta : Graha Ilmu.

${ }^{5}$ https://keuangan.kontan.co.id/. Diakses 26/03/2021. Pukul 22.36 WITA.

6 https://knks.go.id/. Diakses 26/03/2021/ pukul 23.01 WITA.

7 Badan Pusat Statistik Provinsi Nusa Tenggara Barat. 2020. https://ntb.bps.go.id/indicator/23/80/1. Diakses 29 Maret 2021. Pukul. 20.22 WITA.
} 
meningkatkan kemampuan masyarakat untuk mematuhi kebutuhan minimalnya. Artikel ini bertujuan untuk mengetahui bagaimana peran lembaga keuangan syariah dalam pengentasan kemiskinan di Provinsi NTB untuk pengentasan kemiskinan.

\section{STUDI LITERATUR}

\section{Kemiskinan}

Kemiskinan digambarkan sebagai gejala kurangnya pendapatan untuk memenuhi kebutuhan hidup yang pokok. Sekelompok anggota masyarakat dikatakan dibawah garis kemiskinann jika pendapatan kelompok anggota masyarakat tidak cukup untuk memenuhi kebutuhan hidup yang paling pokok seperti pangan, pakaian dan tempat tinggal. Garis kemiskinan menentukan batas minimum pendapatan yang diperlukan untuk memenuhi kebutuhan pokok dapat di pengaruhi oleh tiga hal yaitu : 1) presepsi manusia terhadap kebutuhan yang diperlukan, 2) posisi manusia di dalam lingkungan sekitar, 3) kebutuhan objektif manusia untuk dapat hidup secara manusiawi. ${ }^{8}$

Ekonomi Islam juga memberikan pandangan tentang kemiskinan. Al-Qur'an memandang bahwa kemiskinan adalah masalah sosial yang harus dientaskan. Bahkan penyakit berbahaya yang wajib diobati. Selama ini ada dua strategi yang dilakukan dalam menanggulangi kemiskinan, yaitu rehabilitasi sosial dan pengembangan sosial (social develompment) atau pemberdayaan masyarakat (community empowerment). Pengentasan kemiskinan membutuhkan sinergitas peran antara pemerintah, dan masyarakat. Pengentasan kemiskinan tidak dapat dilakukan hanya dengan ego sektoral, tetapi harus komprehenshif dari berbagai unsur yaitu pemerintah, peran lembaga terkait dan masyarakat sendiri sebagai subjek dan objek perubahan. Pemberdayaan masyarakat berarti meningkatkan kemampuan atau meningkatkan kemandirian masyarakat. Dalam kerangka pembangunan nasional, upaya pemberdayaan masyarakat dapat dilihat dari sudut pandang, penciptaan suasana atau iklim yang memungkinkan masyarakat berkembang; peningkatan kemampuan masyarakat dalam membangun melalui berbagai bantuan dana, pelatihan, pembangunan prasarana dan sarana, baik fisik maupun sosial, serta pengembangan kelembagaan di daerah, perlindungan melalui pemihakan kepada yang lemah untuk mencegah persaingan yang tidak seimbang dan menciptakan kemitraan yang saling menguntungkan. ${ }^{9}$

Beberapa pertimbangan dalam usaha penanggulangan kemiskinan melalui beberapa aspek strategis (Mubyarto, 2002) yaitu : 1) indicator keberhasilan individu perlu dikomplemen dengan

\footnotetext{
${ }^{8}$ Setiadi, dkk. 2013. Konsep Ekonomi Islam dalam Mengentaskan Kesenjangan Sosial : Studi Atas Wacana Filantropi Islam Dalam Syariat Wakaf. JIA. Juni. Nomor 1 Hal 151-166.

${ }^{9}$ Istan, Muhammad. 2017. Pengetasan Kemiskinan Melalui Pemberdayaan Ekonomi Umay Menurut Prespektif Islam. Share: Social Work Jurnal. Volume 6. Nomor 2. Hal 154-272.
} 
Awwalunnisa. Lembaga Keuangan Syariah dan Pengentasan Kemiskinan

prestasi kelompok dan masyarakat. 2) paradigm penanggulangan kemiskinan dengan pengakuan terhadap potensi partisipatif dan modal social kaum miskin untuk mengembangkan diri. 3) kewenangan menentukan sendiri aktivitas penanggulangan kemiskinan, dan meniadakan egosektoral yang bersifat tumpeng tindih, tidak efektif dan kurang efisien. 4) menumbuhkan sendiri prinsip transparasi dan akuntabilitas ditiingkat masyarakat desa. 5) melakukan reposisi peran agen pembangunan menjadi fasilitator pemberdayaan dan 6) percepatan transformasi structural ekonomi perdesaan melalui pengembangan strategi pertumbuhan insklusif sector pertanian dan pedesaan.

\section{Konsep Kemiskinan dalam Ekonomi Islam}

Kemiskinan merupakan suatu keadaan tidak berharta benda atau serba kekurangan atau berpenghasilan sangat rendah. Kemiskinan dalam Bahasa Inggris disebut Poor atau poverty yang berarti the condition of being poor or lock of money. Sedangkan poor adalah lacking riches or needy. Sedangkan dalam Bahasa Arab kemiskinan dikenal dengan istilah Al-miskin atau Al-faqr yang berarti keadaan membutuhkan. Seorang faqir adalah seseorang yang mempunyai sedikit makanan pokok. Sedangkan al-miskin berarti orang yang tidak punya cukup harta untuk memenuhi kebutuhan dirinya dan orang-orang yang menjadi tanggung jawabnya.

Kemiskinan dalam eknomi bukan hanya berkaitan dengan materi dan uang, namun berkaitan pula dengan masalah individu, lingkungan, politik, social dan ekonomi itu sendiri. Kemiskinan merupakan masalah yang dihadapi oleh seluruh negara di dunia yang menjadikannya sebagai suatu masalah yang terus menerus di bahas guna menemukan penanganan yang tepat. Suatu penduduk dikatakan miskin yaitu penduduk yang memiliki penghasilan kurang dari USD 2. Kemiskinan bisa berasal dari individu dan menyebabkan masalah bagi setiap manusia dan sulit diatasi karena merupakan sebuah fitrah manusia. Sikap serba kekurangan dan sikap ingin hidup mewah adalah bukti bahwa kemiskinan akan selalu terjadi.

Ekonomi Islam memandang kekayaan alam dan kekayaan sumber daya manusia harus dilakukan atau diinvestasikan untuk kepentingan manusia pada masa depan, bukan untuk diperjualbelikan. Sumber daya alam yang telah disediakan oleh Allah SWT didunia ini seharusnya menjadi dasar untuk manusia melakukan pengelolaan atasnya sehingga dapat menghasilkan sesuatu bagi manusia. Islam menganjurkan manusia untuk berinvestasi, berdagang dan berbisnis, dengan kemudahan dari segala sumber rezeki dan kekayaan datangnya dari Allah SWT dan bukan dari manusia. Ekonomi Islam justru mendorong agar manusia bersikap rendah hati, tawadhu', kerja keras, tidak boros dan menjauhi dari perbuatan buruk yang menyebabkan kemiskinan. Manusia harus menghindari perbuatan yang mengarah kepada dhalim dan perbuatan 
yang haram dalam mendapatkan harta. Dalam ekonomi Islam terdapat unsur iman, taqwa, syukur, dhalim dan kufur. Kemurahan dan kekayaan akan diperoleh jika manusia dapat berbuat baik terhadap Allah SWT serta senantiasa menjalankan aturan sesuai syariat Islam.

Ekonomi Islam menganjurkan agar manusia rajin bekerja, rajin mencari kemakmuran dan menjauhi sikap monopoli. Unsur utama dalam ekonomi Isalm mengurangi kemiskinan adalah pertama, memperbaiki diri dan meningkatkan kemampuan SDM untuk masa depan. Kedua, memiliki sikap jujur, adil dan tidak boros dalam menjalani hidup serta mengurangi sikap selalu merasa tidak cukup. Ketiga, berinvestasi dengan cara berdagang, bisnis, dan jualbeli secara halal, juga suka bersedekah untuk kepentingan umum dengan harapan dapat mengurangi kemiskinan. Keempat, menghindari transaksi yang mengarah pada riba dan bunga karena akan menyengsarakan diri sendiri. Imam Al-Ghazali menyebutkan bahwa solusi kemiskinan adalah mempunyai bada yang sehat jasmani dan rohani, mempunyai rencana atau pandangan hidup di masa depan dan pemenuhan kebutuhan hidup yakni pakaian dan makanan pokok.

\section{Lembaga Keuangan Syariah}

Lembaga keuangan syariah merupakan Lembaga keuangan yang operasionalnya meggunakan prinsip-prinsip syariah yang terhindar dari unsur riba, gharar dan maisir. Tujuan utama dari Lembaga keuanga syariah adalah untuk menunaikan perintah Allah SWT dalam bidang ekonomi dan muamalah serta membantu membebaskan masyarakat muslim dari kegiatankegiatan yang dilarang oleh ajaran Islam. Lembaga keuangan syariah (LKS) juga diartikan sebagai Lembaga keuangan yang mengeluarkan produk keuangan syariah dan mendapat izin operasional sebagai Lembaga keuangan syariah. Lembaga keuangan syariah merupakan suatu badan usaha atau institusi yang kekayaanya terutama dalam bentuk asset-aset keuangan maupun non finansial asset atau asset rill berlandaskan konsep syariah. ${ }^{10}$ Lembaga keuanga syariah dapat dibedakan menjadi dua yaitu:

a. Lembaga keuangan depository syariah (depository financial institution syariah) yang disebut Lembaga keuangan bank syariah

b. Lembaga keuangan syariah non depository (non depository financial institution syariah) yang disebut Lembaga keuangan syariah bukan bank.

Lembaga keuangan syariah baik bank maupun non bank memiliki spirit Islam baik dalam pelayangan maupun produk-produknya yang di dalam pelaksanaannya diawasi oleh sebuah

\footnotetext{
${ }^{10}$ Rodoni, Ahmad dan Abdul Hamid. 2008. Lembaga Keuangan Syariah. Jakarta:Zikrul Hakim.
} 
Awwalunnisa. Lembaga Keuangan Syariah dan Pengentasan Kemiskinan

Lembaga yang disebut Dewan Pengawasan Syariah (DSN). Lembaga keuangan Islam mempunyai dua peran, yaitu badan usaha (tamwil) dan bada social (maal). Berdasarkan beberapa produk keuangan Islam, Lembaga keuangan Islam selain melaksanakan core bisnisnya pada moneter juga bisa melayani pelayanan terkait pembayaran seperti koperasi, asuransi, gadai, leasing dan Kerjasama bisnis lainnya.

Baitul Maal wa Tamwil (BMT) merupakan Lembaga keuangan Islam mikro yang jangkauannya hingga ke pedesaan. BMT sebuah Lembaga keuangan yang menjadi unit usaha koperasi mengsyaratkan keanggotaan dengan tujuan usaha Bersama pelayanan keuangan yang berorientasi pada kesejahteraan masyarakat. Fungsi dari BMT yaitu 1) mengidentifikasi, memobilasi, mengorganisir, mendorong dan mengembangan potensi serta kemampuan ekonomi anggota, 2) mempertinggi kualitas SDM anggota agar menjadi lebih professional dan islami, 3) menggalang dan mengorganisir potensi masyarakat dalam rangka meningkatkat kesehteraan anggota. ${ }^{11}$ Pada Lembaga BMT disediakan model pinjaman kebijakan (qardhul hasan) membuat BMT tidak memiliki risiko keugian dari kredit macet yang dialokasikan untuk masyarakat paling miskin karena sesuai dengan pemberdayaan maka aktivitas social seperti pengorganisasian dan penguatan kelompok di tingkat komunitas menjadi Langkah awal sebelum masuk pada aktivitas yang mendatangkan profit. $^{12}$ Konsep utama BMT adalah jaminan/proyeksi social melalui pengeloaan dana Baitul maal. Prespektif Baitul Maal Wa Tamwil dinilai postif karena melihat dari semakin besarnya apresiasi masyarakat, pemerintah dan Lembaga-lembaga internasional seperti Islamic Development Bank (IDB), Lembaga Penelitian Australia dan Indonesia dan Lembaga lainnya terkait dengan keberadaan BMT di Indonesia. ${ }^{13}$

\section{METODOLOGI}

Metode yang digunakan dalam penulisan artikel ini ialah analisis deskriptif. Penggunakan metode ini dipilih karena akan menggambarkan secara sistematis fakta dalam peran Lembaga keuangan syariah dalam pengentasan kemiskinan di Provinsi Nusa Tenggara Barat (NTB). Data dan informasi yang digunakan merupakan data sekunder yang diambil dari Badan Pusat Statistik (BPS), Bank Indonesia, Badan Amil Zakat Nasional (BAZNAS), LAZ DASI, Otoritas Jasa Keuangan $(\mathrm{OJK})$, dan beberapa literatur dari peneliti terdahulu dan penulis lainnya.

\footnotetext{
${ }^{11}$ Ridwan, Muhammad. 2004. Manajemen Baitul Maal wa Tamwil (BMT). Yogyakarta: UII Pres.

${ }^{12}$ Majid, Abdul. 2012. Tazkia Islamic Finance and Business.

${ }^{13}$ Muljadi. 2013. Prospektif Baitul Maal Wat Tamwil Dalam Pengentasan Kemiskinan Di Indonesia. Jurnal Perilaku dan Strategi Bisnis. Vol 1. No1. Hal 62-69.
} 


\section{HASIL \& PEMBAHASAN}

\section{Kemiskinan Di Provinsi Nusa Tenggara Barat}

Provinsi Nusa Tenggara Barat (NTB) merupakan salah satu provinsi di Indonesia yang memiliki jumlah penduduk yang mayoritas beragama Islam. Provinsi yang dijuluki sebagai Halal Tourism Island mencerminkan kentalnya kebudayaan Islam di Provinsi ini. Pemerintah provinsi NTB telah menerapkan kebijakan yang sesuai dengan Sustainable Development Goals (SDGs) yang merupakan kelanjutan dari Melliunium Development Goals (MDGs) melalui Rencana Pembangunan Jangka Menengah Daerah (RPJMD) tahun 2019-2023. Pada RJPMD tahun 20092013 pemerintah NTB Menyusun strategi pembangunan dengan melakukan revitalisasi dan akselerasi pelayanan social dasar dan akses terhadap sumberdaya ekonomi. Strategi tersebut dituangkan dalam kebijakan berupa 1) Peningkatan kualitas pelayanan terhadap hak-hak dasar manusia. 2) Peningkata aksesbilitas mayarakat terhadap sumber modal sarana dan prasarana ekonomi. 3) Peningkatan pendapatan masyarakat. Kebijakan tersebut ditempuh melalui 1) Mempercepat pemenuhan pelayanan kebutuhan masyarakat miskin, 2) Mendorong tumbuh dan perkembangnya Lembaga keuangan mikro dan sarana pendukung perekonomi an sampai tingkat pedesaan, 3) Mendorong tumbuh dan berkembangnya pusat-pusat agribisnis, 4) Mendorong timbul dan berkembangnya wilayah strategis dengan cepat tumbuh. ${ }^{14}$

Kebijakan tersebut telah dilaksanankan oleh pemerintah Provinsi NTB secara maksimal sehingga terjadi penurunan jumlah penduduk miskin dari tahun ke tahun. Namun, dalam perjalananya terdapat tantangan yang dihadapi oleh pemerintah NTB yaitu factor internal yang bersasal dari penduduk miskin itu sendiri dan factor eksternal yang berasal dari pelaksana kebijakan serta adanya factor-faktor ekonomi maupun non ekonomi. Dalam RPJMD Provinsi NTB, tingkat kemiskinan masih menjadi prioritas, dimana pengentasan kemisnikan harus didorong dengan dua strategi yaiitu peningkatan kesejahteraan dan menurunkan beban pengeluaran masyarakat. Dengan adanya penurunan jumlah penduduk miskin maka akan pula mempengaruhi prioritas pembangunan lainnya seperti Pendidikan, Kesehatan, pemberdayaan dan lain-lain. ${ }^{15}$ Jumlah penduduk miskin di Provinsi NTB setiap tahunnya mengalami penurunan jika dilihat pada tahun 2012 terdapat sebanyak 840,11 ribu jiwa dan pada tahun 2020 mengalami menurunan menjadi 713,89 ribu jiwa. Angka tersebut juga mempengaruhi angka pertumbuhan kemiskinan di Provinsi NTB yaitu pada tahun 2013 mencapai -2,92\% menjadi -2.99\% pada tahun 2020, hal ini menjadi pencapaian yang baik bagi pemerintah provinsi NTB karena telah mampu menurunkan tingkat kemiskinan di provinsi tersebut.

\footnotetext{
${ }^{14}$ Rencana Pembangunan Jangka Menengah Daerah Provinsi Nusa Tenggara Barat 2009-2013.

${ }^{15}$ Rencana Pembangunan Jangka Menengah Daerah Proviinsi Nusa Tenggara Barat 2019-2023
} 


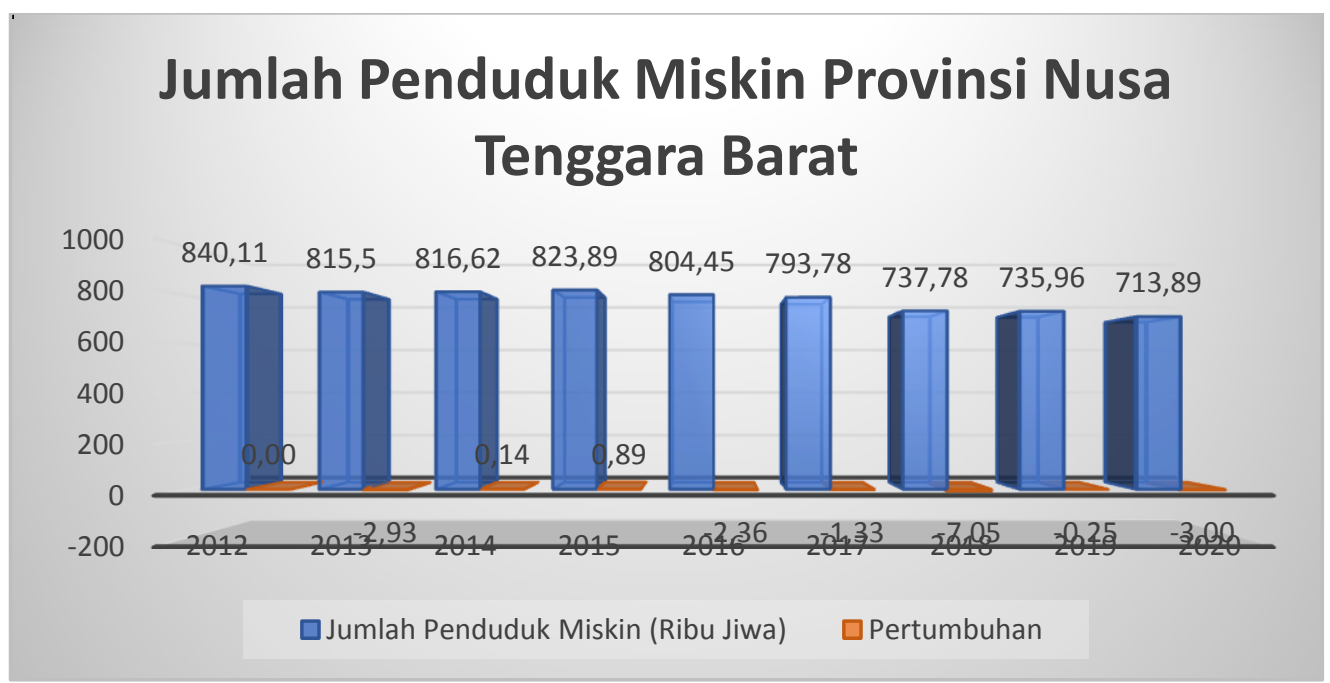

\section{Gambar 1. Jumlah Penduduk Miskin (Dalam Ribu Jiwa) Provinsi Nusa Tenggara Barat} Tahun 2012-2020

Sumber : BPS, diolah

Kondisi kemiskinan di provinsi Nusa Tenggara Barat di dominasi oleh tiga faktor yaitu kemiskinan karena faktor lama pendidikan, tersedianya fasilitas kesehatan dan tersedianya sarana infrastuktur. Tiga kabupaten yang menjadi prioritas pemerintah dalam mengatasi angka kemiskinan berdasarkan faktor-faktor tersebut adalah Kabupaten Lombok Utara, Kabupaten Lombok Barat dan Kabupaten Lombok Timur. Ketiga kabupaten ini menyumbang angka kemiskinan tertinggi jika dibandingkan dengan ke 10 kabupaten/kota yang ada di Provinsi NTB, sehingga pemerintah memberikan perhatian khusus bagi ketiga kabupaten tersebut untuk mengurangi angka kemiskinan pada kabupaten tersebut. Berikut merupakan sebaran angka kemiskinan yang ada di Provinsi NTB.

Tabel 1. Jumlah Penduduk Miskin Berdasarkan Kabupaten/Kota di Provinsi Nusa Tenggara Barat ${ }^{16}$

\begin{tabular}{clrrrrrrrrr}
\hline No & Kabupaten/Kota & \multicolumn{1}{c}{ Jumlah Penduduk Miskin Berdasarkan Kabupaten/Kota (Ribu Jiwa) } \\
\cline { 3 - 10 } & & $\mathbf{2 0 1 2}$ & $\mathbf{2 0 1 3}$ & $\mathbf{2 0 1 4}$ & $\mathbf{2 0 1 5}$ & $\mathbf{2 0 1 6}$ & $\mathbf{2 0 1 7}$ & $\mathbf{2 0 1 8}$ & $\mathbf{2 0 1 9}$ & $\mathbf{2 0 2 0}$ \\
\hline $\mathbf{1}$ & Kabupaten Lombok & 112.1 & 110.9 & 110.7 & 113.3 & 110.8 & 110.6 & 103.7 & 105.0 & 100.2 \\
& Barat & 9 & 9 & 5 & & 5 & 9 & 7 & 4 & 5 \\
$\mathbf{2}$ & Kabupaten Lombok & 148.1 & 145.1 & 145.1 & 147.9 & 145.3 & 142.1 & 130 & 128.8 & 128.1 \\
& Tengah & 5 & 5 & 8 & 4 & 7 & 4 & & 2 & \\
3 & Kabupaten Lombok & 227.8 & 219.5 & 219.6 & 222.1 & 216.1 & 215.8 & 196.8 & 193.5 & 183.8 \\
& Timur & 6 & 6 & 7 & 9 & 8 & 1 & 7 & 6 & 4 \\
$\mathbf{4}$ & Kabupaten & 72.21 & 73.79 & 73.86 & 73.57 & 71.66 & 68.69 & 63.77 & 63.49 & 62.88 \\
\hline
\end{tabular}

${ }^{16}$ BPS Provinsi Nusa Tenggara Barat 


\begin{tabular}{rlrrrrrrrrr}
\hline No & Kabupaten/Kota & \multicolumn{10}{c}{ Jumlah Penduduk Miskin Berdasarkan Kabupaten/Kota (Ribu Jiwa) } \\
\cline { 2 - 10 } & & $\mathbf{2 0 1 2}$ & $\mathbf{2 0 1 3}$ & $\mathbf{2 0 1 4}$ & $\mathbf{2 0 1 5}$ & $\mathbf{2 0 1 6}$ & $\mathbf{2 0 1 7}$ & $\mathbf{2 0 1 8}$ & $\mathbf{2 0 1 9}$ & $\mathbf{2 0 2 0}$ \\
\hline & Sumbawa & & & & & & & & & \\
$\mathbf{5}$ & Kabupaten Dompu & 37.83 & 36.4 & 36.42 & 35.94 & 34.31 & 32.85 & 30.74 & 30.81 & 30.97 \\
$\mathbf{6}$ & Kabupaten Bima & 73.63 & 73.83 & 74.54 & 73.71 & 72.36 & 72.14 & 71.65 & 71.95 & 71.32 \\
$\mathbf{7}$ & Kabupaten & 21.72 & 21.71 & 22.04 & 22.5 & 22.47 & 22.33 & 20.36 & 20.45 & 20.2 \\
& Sumbawa Barat & & & & & & & & & \\
$\mathbf{8}$ & Kabupaten Lombok & 74.16 & 72.16 & 72.19 & 72.28 & 71.02 & 69.24 & 62.86 & 63.84 & 59.86 \\
& Utara & & & & & & & & & \\
$\mathbf{9}$ & Kota Mataram & 50.48 & 46.67 & 46.67 & 46.76 & 44.81 & 44.53 & 42.6 & 43.19 & 41.8 \\
$\mathbf{1 0}$ & Kota Bima & 15.88 & 15.25 & 15.31 & 15.7 & 15.42 & 15.36 & 14.84 & 14.8 & 14.66 \\
$\mathbf{1 1}$ & Nusa Tenggara & $\mathbf{8 4 0 . 1}$ & $\mathbf{8 1 5 . 5}$ & $\mathbf{8 1 6 . 6}$ & $\mathbf{8 2 3 . 8}$ & $\mathbf{8 0 4 . 4}$ & $\mathbf{7 9 3 . 7}$ & $\mathbf{7 3 7 . 4}$ & $\mathbf{7 3 5 . 9}$ & $\mathbf{7 1 3 . 8}$ \\
& Barat & $\mathbf{1}$ & & $\mathbf{2}$ & $\mathbf{9}$ & $\mathbf{5}$ & $\mathbf{8}$ & $\mathbf{6}$ & $\mathbf{6}$ & $\mathbf{9}$ \\
\hline
\end{tabular}

Sumber : BPS, diolah.

Berdasarkan data diatas menggambarkan bahwa pemerintah provinsi NTB memiliki focus yang besar dalam mengatasi masalah kemiskinan di provinsi NTB, penurunan yang terus terjadi disetiap tahunnya dapat membuktikan bahwa pemerintah provinsi NTB telah berhasil menjalankan strategi-strategi yang tercatat dalam RPJMD proovinsi NTB dan menjalankan komitmen yang tertuang dalam SDGs, walaupun memang secara nasional keadaan kemiskinan di Indonesia masih sangat tinggi. Kemiskinan yang terjadi di provinsi Nusa Tenggara Barat dipengaruhi oleh income perkapita, dimana pendapatan merupakan factor yang diandalkan dalam sector pertanian, kehutanan, dan perikanan, perdagangan besar dan eceran. Pengetasan kemiskinan melalui pendapatan perkapita dapat dilakkan dengan melakukan pengembangan ekonomi local melalui dana desa dan meningkatkan efektivitas sasaran dan mekanisme dan implementasi program penanggulangan kemiskinan. ${ }^{17}$

Hasil penelitian yang dilakukan oleh Irwan (2017) menyebutkan bahwa jumlah penduduk miskin tinggi berada di daerah pedesaan. ${ }^{18}$ Angka kemiskinan pada daerah pedesaan masih lebih tinggi jika dibandingkan dengan daerah perkotaan. Hal ini jua didukung oleh data pada table di atas dimana angka jumlah penduduk miskin terbanyak tercatat pada kabupaten Lombok Timur sebanyak 183,84 ribu jiwa jika dibandingkan dengan kota Mataram sebesar 41,8 ribu jiwa pada tahun 2020. Pada dasarnya angka kemiskinan pada kota dan kabupaten di provinsi NTB mengalami penurunan walaupun pada Kota Mataram dan Kabupaten Dompu mengalami kenaikan pada tahun 2020 sekitar 1.600 jiwa. Hal ini bisa saja dipengaruhi dengan adanya

\footnotetext{
${ }^{17}$ Permono, Adia Islami, dkk. 2019. Analisis Indikator Kemiskinan Provinsi Nusa Tenggara Barata Tahun 2019.

${ }^{18}$ Irwan, M. 2017. Indeks Kedalaman Dan Keparahan Kemiskinan Di Provinsi Nusa Tenggara Barat Dan Penanganannya Dalam Ekonomi Islam. Ekonobis. Volume 3. No.2. September 2017. Hal 111-135.
} 
Awwalunnisa. Lembaga Keuangan Syariah dan Pengentasan Kemiskinan

pandemic Covid-19 yang akhirnya mempengaruhi kegiatan ekonomi masayarakat. Masalah kemiskinan bukanlah tanggung jawab dari pemerintah melalui program-program dan dana yang dialokasikan, lebih lanjut masalah kemiskinan ini menjadi tanggung jawab seluruh masyarakat umum dengan berkontribusi membarikan bantuan atau jaminan terhadap penduduk miskin. Islam sebagai agama mayoritas yang dianut oleh masyarakat di Indonesia termasuk provinsi NTB, telah memiliki instrument untuk mengatasi masalah kemiskinan ini yaitu melalui jaminan social berupa zakat.

\section{Pengentasan Kemiskinan Melalui Zakat}

Penanganan kemiskinan dalam ajaran Islam dapat dilakukan dengan banyak cara baik yang bersifat tuntunan wajib, Sunnah maupun sukarela. Tuntunan pengentasan kemiskinan sebagaimana yang diidentifikasi oleh Qardhawi (1996) adalah 1) Bekerja, 2) Jaminan sanak family yang berkelapangan, 3) Zakat, 4) Jaminan baitul mal, 5) Berbagai kewajiban diluar zakat, 6) sekedah sukarela dan kemurahan hati individu. Cara-cara tersebut dalam Islam tidak terlepas dari aktivitas ekonomi, baik berkenaan langsung dengan penyandang kemiskinan maupun dating dari pihak lain yang tertuju kepada golongan penyandang kemiskinan. Pengentasan kemiskinan dikaitkan dengan aktivitas ekonmi lebih banyak berada pada aktivitas ekonomi. Pengentasan kemiskinan dikaitkan dengan aktivitas distribusi. Oleh karenanya, pada analisis ini pengetasan kemiskinan hanya dilihat dari satu dimensi yaitu zakat.

Pengentasan kemiskinan di provinsi NTB melalui program-program yang telah direncanakan oleh pemerintah pusat maupun pemerintah daerah dengan berpihak kepada orang miskin. Keseriusan pemerintah provinsi NTB dalam menangani kemiskinan dilihat dengan digadengnya Badan Amil Zakat Nasional (BAZNAS) Provinsi NTB untuk sama-sama mengentaskan kemiskinan. BAZNAS yang dipercayai untuk menghimpun dana zakat dari para muzzaki telah berusaha untuk menghimpun dana zakat secara maksimal, selain itu, BAZNAS juga menghimpun dana infaq dan sedekah yang juga diperuntukkan untuk penduduk-penduduk yang tergolong mustahik maupun yang tidak tergolong mustahik. Penghimpunan dana yang berasal dari masyarakat terutama zakat oleh BAZNAS sebagai implementasi dan tugas BAZNAS sebagai salah satu lembaga keuangan Islam nonbank yang berperan sebagai mediasi antara muzakki dengan pihak mustahik. Peranan zakat di provinsi NTB telah memberikan hasil, setidaknnya menurunnya presentasi penduduk miskin dari tahun ke tahun telah menunjukkan bahwa zakat telah berkontibusi di dalamnya. Penggunaan dana zakat untuk diberikan kepada delapan golongan tidak hanya dengan memberikan uang secara gratis dan habis digunakan untuk memenuhi kebutuhan hidup. Penyaluran dana zakat untuk diberikan kepada delapan golongan 
tidak hanya dengan memberikan uang secara gratis dan habis digunakan untuk memenuhi kebutuhan hidup. Penyaluran dana juga digunakan untuk menfasilitasi pengembangan sekolahsekolah maupun untuk biaya pendidikan anak-anak yang tergolong miskin mulai dari jejaring sekolah dasar hingga perguruan tinggi.

Keterlibatan negara dalam mengelola dana zakat dengan dibentuknya BAZNAS menggambarkan bahwa negara memiliki harapan besar dari dana zakat sebagai sumber pendapatan negara. Perjalanan BAZNAS telah mengalami perkembangan meskipun dalam perjalanannya masih ada tantangan berkaitan dengan besarnya potensi yang belum mampu dikumpulkan sebagai sumber zakat yang permanen. Adanya kerjasama BAZNAS sebagai lembaga dan masyarakat wajib zakat (muzakki) akan menciptakan hubungan yang baik dalam usaha mewujudkan dana zakat sebagai keuangan Islam yang utama. Zakat sebagai instrument yang ditetapkan Islam untuk mengatasi masalah kemiskinan. Berdasarkan sumbernya, zakat bisa diambil dari hasil pertanian, hasil ternak, barang dagangan, barang temuan dan hasil tambang serta emas dan perak.

Zakat juga bisa bersumber dari zakat profesi, zakat perusahaan, zakat surat-surat berharga, zakat property dan zakat asuransi syariah. ${ }^{19}$ Tujuan penghimpunan zakat professional berdasarkan Undang-Undang Nomor 23 Tahun 2011 adalah untuk membantu mengentaskan masalah kemiskinan, selain itu menjadi symbol dan keharmonisan hubungan sesame manusia. Hal tersebut dapat terealisasikan jika penghimpunan zakat dikelola secara professional oleh orang-orang yang ahli di bidangnya serta menerapkan prinsip yang baik dan benar sesuai dengan perkembangan zaman, namun tetap berpedoman pada tata cara pengelolaan zakat yang dipraktikkan oleh Rasulullah SAW, maka zakat akan menjadi solusi atas permasalahan umat. ${ }^{20}$

Usaha yang dilakukan BAZNAS Provinsi NTB dalam mengentaskan kemiskinan yang ada di provinsi NTB adalah dengan menerima zakat dari para muzzaki dan melanyurkannya kepada pihak-pihak yang membutuhkan. Dalam hal penyaluran dana zakat yang di terima oleh BAZNAS, Lembaga ini telah memiliki program-program agar zakat ini sampai kepada golongan depalan asnaf yaitu, pemberian santunan kepada fakir miskin pada setiap bulannya, memberikan modal kepada pedagang yang tidak memiliki tempat permanen untuk berjualan, pemberian modal dana bergulir kepada pengusaha mikro, pemberian gaji tunai perbulan yang diperuntukkan untuk marbot-marbot masjid, santunan untuk lansia dan beasiswa untuk pelajar atau mahasiswa

\footnotetext{
${ }^{19}$ Fakrudin. 2008. Fiqh dan Manajemen Zakat di Indonesia. UIN Malang Press. Malang.

${ }^{20}$ Sularno, M. 2010. Pengelolaan Zakat Oleh Badan Amil Zakat Daerah Kabupaten/Kota SeDaerah Istimewa Yogyakarta. Jurnal La_Riba : Jurnal EKonomi Islam. IV(1).
} 
berprestasi $^{21}$. Namun terdapat pula factor-faktor penghabat yang dialami oleh BAZNAS antara lain masih kurangnya kesadaran umat Islam untuk berzakat, pelaksanaan zakat masih dilakukan secara tradisional, kurangnya kepercayaan terhadap Lembaga pengelolaan zakat, belum tersosialisasinya secara optimal peraturan perundang-undangan tentang zakat.

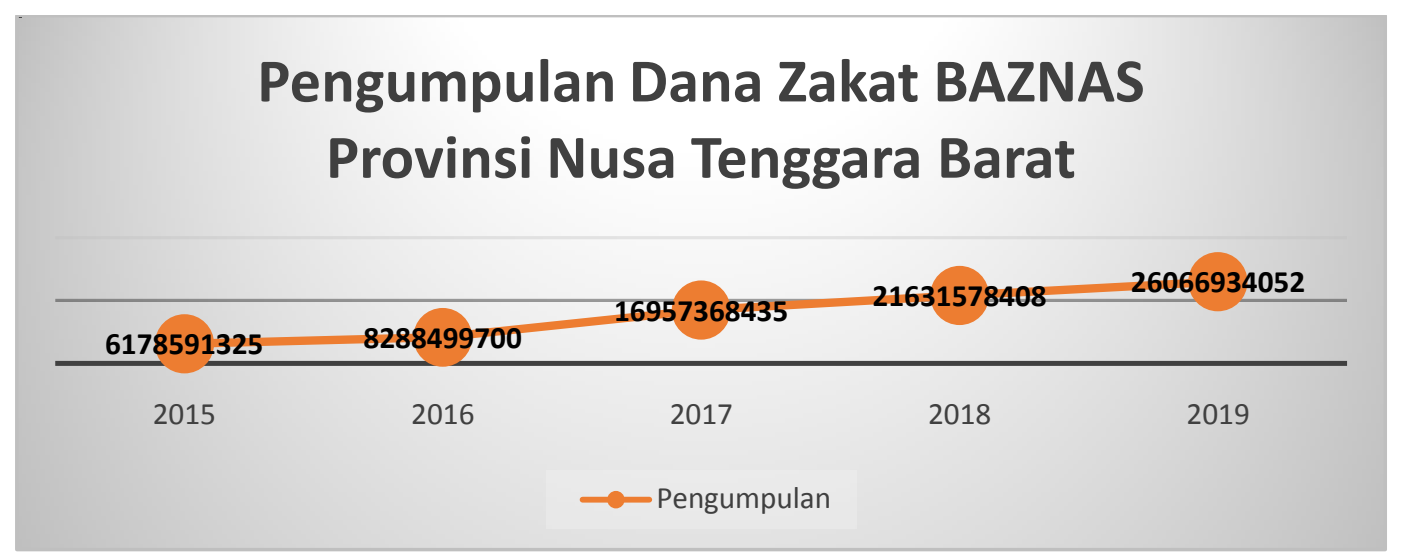

\section{Gambar 2. Pengumpulan Dana Zakat pada Badan Amil Zakat Nasional (BAZNAS) Provinsi Nusa Tenggara Barat Tahun 2015-2019}

Sumber: BAZNAS Provinsi Nusa Tenggara Barat, diolah.

Penerimaan dana zakat pada BAZNAS Privinsi NTB pada tahun 2015-2019 mengalami peningkatan, dimana pada tahun 2015 BAZNAS Provinsi NTB menerima dana zakat sebesar Rp. 6.178.591325,- dan meingkat disetiap tahunnya sehingga pada tahun 2019 BAZNAS provinsi NTB menerima dana zakat sebesar Rp. 26.066.934.052,-. Hal ini membuktikan mulai adanya kesadaran masyarakat untuk menyalurkan zakatnya melalui Lembaga yaitu BAZNAS. Pada tahun 2018 BAZNAS provinsi NTB dapat menyalurkan dana zakat sebesar Rp.19.475.849.932,- dan Rp. 22.179.547.760,- pada tahun 2019. Zakat sebagai pilar ekonomi kerakyatan seharusnya mampu membantu pengentasan kemiskinan, maka dibutuhkan kesadaran Bersama para pelaku zakat baik nasional ataupun daerah. Oleh karenanya butuh pula sosialisasi kepada masyarakat tentang pentingnya zakat serta memberikan kepercayaan kepada masyarakat untuk mempercayakan dana zakatnya kepada Lembaga zakat dalam hal ini yaitu BAZNAS. Secara keseluruhan BAZNAS NTB telah mengeluarkan segala kemampuan untuk mewujudkan masyarakat yang sejahtera melalui pendistribusian dana zakat yang dimiliki dengan cara sosialisi dan Kerjasama dengan berbagai pihak, walaupun haslnya masih belum bisa dirasakan maksimal oleh masyarakat secara umum.

\footnotetext{
${ }^{21}$ Ibid.

${ }^{22}$ Baznasntb.or.id. diakses pada tanggal 23/03/2021 pukul 07.58 WITA.
} 


\section{Pengentasan Kemiskinan Melalui Lembaga Keuangan Syariah}

Lembaga keuangan syariah merupakan institusi di bidang jasa keuangan yang bergerak dengan cara menghimpun dana dari masyarakat dan menyalurkannya kembali melalui pendanaan. Manfaat dari lembaga keuangan ini yaitu untuk mndapatkan uang tunai sehingga tidak aka nada kekhawatiran akan kurangnya ketersediaan uang tunai yang beredar di masyarakat. Lembaga keuangan juan berperan sebagai wadah untuk kegiatan pengalihan asset dengan cara menyalurkan dana kepihak lain untuk dikelola dalam waktu tertentu. Manfaat lain dari lembaga keuangan yaitu mempermudah transaksi keuangan. Dengan adanya lembaga ini, masyarakat bias menghemat waktu dan tenaga dalam melakukan kegiatan yang berhubungan dengan keuangan. Lembaga keuangan syariah merupakan Lembaga yang menerapkan system non bunga. Bank syariah memiliki prinsip dan basis operasional yang terintegrasi dengan nilai social dan aktifitas ekonomi.

Upaya dalam pengentasan kemiskina dapat dilakukan dengan memperluas akses Usaha Mikro, Kecil dan Menengah (UMKM) dalam mendapatkan fasilitas permodalan yang tidak hanya bersumber dari perbankan konvensional dan koperasi, namun juga melalui perbankan syariah. Perbankan syariah dengan prinsip produknya yaitu bagi hasil yang dikenal sebagai pembiayaan mudharabah, pada dasarnya pembiayaan ini bersifat produktif karena diinvestasikan untuk penyediaan modal kerja sehingga dapat memberdayakan perekonomian masyarakat kecil melalui Usaha Mikro, Kecil dan Menengah (UMKM). Pemberdayaan UMKM dapat menjadi upaya untuk membuka lapangan kerja baru yang dapat meningkatkan pendapatan masyarakat dan mengurangi angka pengangguran atau angka kemiskinan. Sesuai denga prinsip perbankan syariah, pembiayaan mudharabah seharusnya dapat memberikan dampak yang positif terhadap perkembangan sector rill termasuk UMKM yang menjadi tonggak dalam kemajuan perekonomian negara melalui kegiatan investasi. ${ }^{23}$

Lembaga keuangan mikro merupakan Lembaga alternatif bagi masyarakat yang tidak bisa memperoleh dana dari bank yang merupakan Lembaga pendanaan yang ramai di tengah-tengah masyarakat. Proses penyaluran dana pada Lembaga keuangan mikro dilakukan secara sederhana, murah dan mudah dengan prinsip keperpihakan kepada masyarakat kecil dan berasas pada keadilan. Prinsip pada Lembaga ini adalah memobilasi dana dari kelompok masyarakat yang memiliki kelebihan dana yang kemudian disalurkan Kembali kepada kelompok masyarakat yang memiliki kekurangan dana. Terdapat dua cara dalam menjalankan Lembaga keuangan mikro ini

\footnotetext{
${ }^{23}$ Arianto, Dwi Agung Nugroho. 2011. Peranan Al-Mudharabah Sebagai Salah Satu Produk Perbankan Syaroah Dalam Upaya Mengentaskan Kemiskinan Di Indonesia. Jurnal Ekonomi \& Pendidikan. Volume 8 Nomor 2, November 2011.
} 
yaitu dengan menggunakan system bunga bagi Lembaga keuangan mikro konvensional dan menggunakan system profit sharing atau konsep syirkah (bagi hasil) bagi Lembaga keuanngan berbasis syariah. ${ }^{24}$

Baitul maal wattamwil (BMT) merupakan lembaga pendukung kegiatan ekonomi masyarakat kecil yang berlandaskan syariah yang berfungsi unutk pengumpulan dana zakat, infaq, sadaqah dan wakaf dan sumber dana social lainnya. Seiring dengan perkembangannya BMT mengembangkan usahanya pada sector keuangan seperti simpan pinajm yang menghimpun dana dari anggota dan calon anggota (nasabah) serta menyalurkannya kepada sector ekonomi yang halal dan menguntungkan. Dalam proses pengembangan usaha kecil dan mikro di provinsi NTB, para pelaku usaha dapat mengakses dana (modal) akan selalu berhubungan dengan lembaga keuangan yang terorganisir yang bersentuhan langsung dengan masyarakat tanpa prosedur yang menyulitkan dan bunga yang berlipat ganda. Perkembangan IKMS (KSPPS/USPPS,BMT,Kopontren,dll) di provinsi NTB pada tahun 2017 sebanyak 33, pada tahun 2018 sebanyak 50 dan meningkat pada tahun 2019 sebanyak 2019 dengan jumlah anggota sebanya 14.426 orang, jumlah modal sendiri mencapai 25,5 Miliar pada tahun 2019. ${ }^{25}$

Perkembangan BMT di provinsi NTB dapat mebantu para pelaku usaha kecil dan menengah untuk mendapatkan modal usaha agar usahanya dapat berjalan dengan baik. Lokasi BMT yang dekat dengan nasabah dan pusat ekonomi dapat memberikan bantuan permodalam usaha kepada masyarakat miskin atau masyarakat menengah kebawah sehingga dapat membatu pengentasan kemiskinan di provinsi NTB. Namun dalam perjalanannya terdapat pula tantangan yang dihadapi oleh BMT yang ada di provinsi NTB salah satunya yaitu kurangnya sosialisasi dan promosi sehingga banyak masyarakat yang belum memahami manfaat dari hadirnya BMT mengingat banyaknya persaingan dengan bank syariah yang mulai mencanangkan program untuk sector mikro yang dapat membuat nasabah akan pindah untuk melakukan transaksi di bank syariah. Oleh karenanya dibutuhkan pengembangan diri yang dilakukan oleh BMT secara kreatif, inovatif dan selalu memberikan pelayanan yang baik kepada nasabah BMT dan didukung oleh adanya sarana dan presarana yang diberkan oleh pemerintah daerah ataupun pusat sehingga dapat membuat BMT berkembang dengan baik.

\footnotetext{
${ }^{24}$ Situmorang, James. 2007. Kaji Teknik Peningkatan Koperasi dan UKM Sebagai Lembaga Keuangan Alternatif, Jurnal Infokop. Vol.2 Juli. 24-35.

${ }^{25}$ Knks.go.id/ diakses 25/03/2021. Pukul. 20.13 WITA.
} 


\section{SIMPULAN}

Jumlah penduduk miskin di Indonesia pada tahun 2020 mengalami peningkatan jika dibandingkan dengan dua tahun sebelumnya. Salah satu alasan terjadinya peningkatan jumlah penduduk miskin ini karena terjadinya bencana global berupa pandemic covid-19 yang mengharuskan seluruh manusia di dunia melakukan adaptasi terhadap keadaan baru. Pandemic yang telah mengganggu seluruh aktivitas manusia secara keseluruhan termasuk dalam kegiatan ekonomi, mengakibatkan beberapa orang kehilangan pekerjaan dan mata pencaharian. Walaupun secara nasional jumlah penduduk miskin mengalami kenaikan, namun secara regional di Provinsi NTB menunjukkan jumlah penduduk miskin yang menurun pada tahun 2020.

Secara keseluruhan pemerintah baik pada tingkat nasional dan regional telah memikirkan dan menyediakan program-progam khusus untuk mengatasi tingkat kemiskinan. Namun, dengan bertambahnya jumlah penduduk memaksa pemerintah melakukan pembaharuan dalam kebijakan pengentasan kemiskinan tersebut. Dalam ekonomi Islam telah diajarkan untuk menggunakan zakat dalam mengatasi kemiskinan sehingga mencapai kesetaraan kesenjangan social. Hal ini sesuai dengan tujuan SDGs yang ingin menghapus angka kemiskinan di masinng-masing negara di dunia. Selanjutnya dengan adanya Lembaga keuangan syariah dapat membantu masyarakat miskin dalam hal pendanaan tanpa harus menggunakan system bunga yang terkadang menyiksa. Kesadaran masyarakat di Provinsi NTB untuk membayar zakat dikatakan sudah sangat baik jika dilihat dari banyaknya dana zakat yang disalurkan demikian pula dengan kesadaran menggunakan Lembaga keuangan syariah yang nantinya diharapkan dapat membantu pendanaan bagi rakyat menengah kebawah. Pemerintah seharusnya mempunyai komitmen yang kuat untuk mengentaskan kemiskinan khususnya di Provinsi Nusa Tenggara Barat yang nantinya akan mempengaruhi angka kemiskinan secara nasional. Namun, apapun bentuk kegiatan program yang diterapkan pemerintah provinsi NTB tanpa adanya dukungan dari masyarakat akan menjadi kurang maksimal atau akan jauh dari harapan. Oleh karenanya dalam pengentasan kemiskinan, seluruh elemen masyarakat juga bekerja Bersama-sama mendukung program baik dari pemerintah maupun Lembaga lainnya dalam upaya pengentasan kemiskinan ini.

\section{REFERENSI}

Afifudin. Tati Atmayanti. 2020. Pengaruh Pertumbuhan Ekonomi Terhadap Kemiskinan Di Provinsi Nusa Tenggara Barat: Prespektif Ekonomi Islam. Jurnal Kompetitif. Vol 6. No.1. Maret 2020. Hal 26-42. 
Awwalunnisa. Lembaga Keuangan Syariah dan Pengentasan Kemiskinan

Arianto, Dwi Agung Nugroho. 2011. Peranan Al-Mudharabah Sebagai Salah Satu Produk Perbankan Syariah Dalam Upaya Mengentaskan Kemiskinan Di Indonesia. Jurnal Ekonomi \& Pendidikan. Voume 8 Nomor 2, November 2011.

Badan Pusat Statistik. 2014. Kajian Indikator Sustainable Development Goals (SDGs). Jakarta : Badan Pusat Statistik.

Fakhrudin. 2008. Fiqh dan Manajemen Zakat di Indonesia. UIN Malang Press. Malang.

Hamzah. 2012. Kebijakan Penanggulangan Kemiskinan dan Kelaparan di Indonesia: Realita dan Pembelajaran. Jurnal AKK. Vol.1.No.1. September. Hal : 1-55.

Herwanti, Titiek. Muhammad Irwan. Siti Maryam. 2020. Peranan Zakat Sebagai Instrumen

Pengentasan Kemiskinan Di Kota Mataram. Elastisitas : Jurnal Ekonomi Pembangunan.

Vol.2. No.1. Maret 2020. Hal. 72-86.

https://baznasntb.or.id/. Diakses pada tanggal 23 Maret 2021. Pukul 07.58 WITA.

https://knks.go.id/. DIakses pada tanggal 25 Maret 2021. Pukul 20.13 WITA.

https://www.bps.go.id/pressrelease/2021/02/15/1851. Diakses pada tanggal 29 Maret 2021.

Pukul 19.15 WITA.

https://keuangan.kontan.co.id/. Diakses 26/03/2021. Pukul 22.36 WITA.

http://sdgs.bappenas.go.id. Diakses pada tanggal 29 Maret 2021. Pukul 20.04 WITA.

https://ntb.bps.go.id/indicator/23/80/1. Diakses pada tanggal 29 Maret 2021. Pukul. 20.22 WITA.

http://sdgs.bappenas.go.id. Dikases pada tanggal 29 Maret 2021. Pukul 22.20 WITA.

Irwan, M. 2017. Indeks Kedalaman Dan Keparahan Kemiskinan Di Provinsi Nusa Tenggara

Barat Dan Penanganannya Dalam Ekonomi Islam. Ekonobis. Volume 3. No.2. September 2017. Hal 111-135.

Ishartono dan Santoso Tri Raharjo. Sustainable Develompoent Goals (SDGs) dan Pengentasan

Kemiskinan. Share : Social Work Jurnal. Volume:6. Nomor:2. Hal 154-272.

Istan, Muhammad. 2017. Pengetasan Kemiskinan Melalui Pemberdayaan Ekonomi Umat Menurut Prespektif Islam. Al Falah : Journal of Islamic Economics. Vol.2. No.1.

Jawas, Yazid Bin Abdul Qadir. 2018. Kiat-Kiat Islam Mengatasi Kemiskinan. Bogor: Pustaka AtTaqwa.

Kamarnis dan Tri Lestari H. Penanggulangan Kemisikinan Dalam Pencapaian Millennium Development Goals (MDGs). Serat Acitya Jurnal Ilmiah. UNTAG Semarang.

Mimbar, L. 2015. Peran Badan Pemberdayaan Masyarakat dan Pemerintahan (BPMPD) dalam

Penanggulangan Kemiskinan di Nusa Tenggara Barat. Jurnal Tranformasi P2M IAIN Mataram. Vol.11, No.1. Januari-Juni. 
Majid, Abdul.2012. Tazkia Islamic Finance and Business.

Muhammad. 2009. Lembaga Keuangan Mikro Syariah : Pergulatan Melawan Kemiskinan \& Penetrasi Ekonomi Global. Yogyakarta : Graha Ilmu.

Muljadi. 2013. Prospektif Baitul Maal Wat Tamwil Dalam Pengentasan Kemiskinan di Indonesia. Jurnal Perilaku dan Strategi Bisnis. Vol 1 No 1. Hal 62-69.

Munawaroh, Aflah Binti. 2020. Pemberdayaan Zakat Untuk Pengetasan Kemiskinan. ES A Jurnal Ekonomi Syariah. Volume 3. Nomor 2. Desember 2020. Hal. 227-247

Pratama, Nanda Bhayu. Eko Priyo Purnomo. Agustiyara. 2020. Sustainable Development Goals (SDGs) Dan Pengetasan Kemiskinan Di Daerah Istimewa Yogyakarta. Jurnal Ilmiah Sosial Dan Humaniora: SOSIOHUMANIORA. Volume 6 (2). Agustus 2020. Hal 64-74.

Permono, Adia Islami, dkk. 2019. Analisis Indikator Kemiskinan Provinsi Nusa Tenggara Barata Tahun 2019.

Riadi, Selamat. 2020. Strategi Distribusi Zakat dan Pemberdayaan Mustahik: Studi Kasus BAZNAS Kota Mataram. Schemata Jurnal Pascasarjana LAIN Mataram. Vol.9 No.1, Juni 2020. 125-136.

Ridlo, Musalim. Ahmad Mifdol Muthohar. 2020. Analisis Pengarub Zakat, Pembiayaan Syariah Dan APBN Terbadap Pengetasan Kemiskinan Di Indonesia Dan Malaysia. Jurnal Dinamika Ekonomi Dan Bisnis. Vol. 17 (02) 2020. Hal 123-130.

Ridwan, Muh. 2004. Manajemen Baitul Maal wa Tamwil (BMT). Yogyakarta: UII Press.

Rodoni, Ahmad dan Abdul Hamid. 2008. Lembaga Kenangan Syariah. Jakarta: Zikrul Hakim.

Salahuddin, Muh. 2013. Lembaga Kenangan Syariah Non-Bank (Demokratisasi Ekonomi Menuju Kesejabteraan Masyarakat NTB). Mataram : Lentera Peduli.

Sanwani, dkk. 2017. Strategi Penghimpunan dan Penyaluran Dana pada Baitul Maal Wat Tamwil (BMT) Al-Hidayah di Kabupaten Lombok Timur. Iqtishoduna. Vol. 6. No.1 April 2017.

Sakni, Ahmad Soleh. 2013. Konsep Ekonomi Islam dalam Mengentaskan Kesenjangan Sosial : Studi atas Wacana Filantropi Islam dalam Syariat Wakaf. JIA. Juni. Nomor 1. Hal 151166.

Setiadi, Elly M dan Usman Kolip. 2011. Pengantar Sosiologi Pemahaman Fakta dan Gejala Permasalah Sosial: Teori, Aplikasi dan Pemecahannya. Jakarta : Kencana.

Situmorang, James. 2007. Kaji Tindak Peningkatan Peran Koperasi dan UKM sebagai Lembaga Keuangan Alternatif. Jurnal Infokop. Vol.2. Juli. 24-35.

Sularno, M. 2010. Pengelolaan Zakat Oleh Badan Amil Zakat Daerah Kabupaten/Kota Se Daerah Istimewa Yogyakarta. Jurnal La_Riba : Jurnal Ekonomi Islam. IV(1). 
Awwalunnisa. Lembaga Keuangan Syariah dan Pengentasan Kemiskinan

Suradi. 2007. Pembangunan Manusia, Kemiskinan dan Kesejahteraan Sosial : Kajian tentang Kebijakan Pembangunan Kesejahteraan Sosial di Nusa Tenggara Barat. Jurnal Penelitian dan Pengembangan Kesejabteraan Sosial. Vol.12. No.3. hal. 1-11.

Suriadi, Irwan. 2018. Peluang dan Tantangan Lembaga Keuangan Mikro Syariah (BMT) dalam Mengurangi Kemiskinan di Nusa Tenggara Barat. Ekonobis. Volume 4. No. 1. Maret.

Stamboel, Kemal A. 2012. Panggilan Keberpihakan, Strategoo Mengakbiri Kemiskinan di Indonesia. Jakarta : PT. Gramedia Pustaka Utama.

Sriyana, Jaka dan Fitri Raya. 2013. Peran BMT Dalam Mengatasi Kemiskinan di Kabupaten Bantul. INFERENSI Jurnal Penelitian Sosial Keagaman. Vol 7 No 1, Juni. 